\title{
DETERMINAN SIKLUS KONVERSI KAS INDUSTRI MANUFAKTUR DI INDONESIA \\ (Studi pada Perusahaan Manufaktur yang Terdaftar di Bursa Efek Indonesia)
}

\author{
Muhammad Madyan', Iqbal Rizqy Rahmaddian', Novian Abdi Firdausi ${ }^{2}$ \\ ${ }^{1}$ Departemen Manajemen Fakultas Ekonomi dan Bisnis Universitas Airlangga \\ ${ }^{2}$ Departemen Ekonomi Islam Fakultas Ekonomi dan Bisnis Universitas Airlangga \\ novianfirdausi@gmail.com
}

\begin{abstract}
This research aims to asses and analyse the determinants of cash conversion cycle on manufacture industry in Indonesia. Determinant variables of cash conversion cycle used in this research are firm size, sales growth, profitability, debt ratio, quick ratio, and operating cash flow. Data used are from financial statements of manufacture firms which listed in Indonesia Stock Exchange and fulfill research requirements, amount to 128 companies in time period of 2007-2011. Results of the study show that profitability, operating cash flow, and firm size have significant effect on cash conversion cycle. Whereas sales growth, debt ratio, and quick ratio have insignificant effect on cash conversion cycle.
\end{abstract}

Keywords: Cash Conversion Cycle, Manufacture Industry, Working Capital Management.

\begin{abstract}
Abstrak: Penelitian ini bertujuan untuk menguji dan menganalisis determinan siklus konversi kas pada industri manufaktur di Indonesia. Variabel determinan siklus konversi kas yang digunakan pada penelitian ini adalah ukuran perusahaan, pertumbuhan penjualan, profitabilitas, debt ratio, quick ratio dan operating cash flow. Data yang digunakan adalah laporan keuangan perusahaan manufaktur yang terdaftar di Bursa Efek Indonesia dan memenuhi kelengkapan studi sejumlah 128 perusahaan dalam jangka waktu 2007-2011. Hasil penelitian ini menunjukkan bahwa profitabilitas, operating cash flow, ukuran perusahaan berpengaruh signifikan pada siklus konversi kas. Sedangkan variabel pertumbuhan penjualan, debt ratio, dan quick ratio berpengaruh tidak signifikan terhadap siklus konversi kas.
\end{abstract}

Katakunci: Industri Manufaktur, Manajemen Modal Kerja, Siklus Konversi Kas

Zaman globalisasi yang berkembang membuka peluang perekonomian Indonesia untuk berkembang. Kondisi finansial dan perkembangan perusahaan menjadi tuntutan utama dalam persaingan antar perusahaan. Suatu perusahaan dapat dikatakan berhasil jika manajemennya mampu melihat kemungkinan dan kesempatan di masa mendatang, baik jangka panjang maupun jangka pendek.

Dengan mengetahui determinan profitabilitas, perusahaan dapat mengambil langkah tepat untuk mengatasi dan meminimalisir dampak negatif yang timbul. Semua faktor yang ada dalam sebuah perusahaan memiliki pengaruh pada kemampuan perusahaan untuk meraup laba. Dewasa ini, pencapaian profitabilitas tidak hanya terpaut pada laba yang besar saja, tetapi juga mengelola modal kerja untuk meningkatkan profitabilitas.

Kas atau keuangan dapat diibaratkan seperti darah dalam bisnis dan manajemen.
Meningkatkan jumlah kas tersedia membuat perusahaan tidak membutuhkan pendanaan dari luar (Weston \& Brigham, 2005). Ketersediaan kas juga berguna saat perusahaan membayar gaji, upah, distribusi, dan melunasi hutang.

Baik buruknya kinerja suatu perusahaan dapat diukur dari pengaturan manajemen modal kerja. Raheman \& Nasr (2007) menyatakan bahwa manajemen modal kerja yang efisien melibatkan pengunaan aktiva lancar dan kewajiban lancar dalam rangka mengurangi risiko ketidakmampuan pemenuhan kewajiban jangka pendek, serta menghindari investasi berlebih pada aset perusahaan. Konsep manajemen modal kerja juga merujuk pada kemampuan manajer dalam menangani investasi jangka pendek dengan tujuan untuk meningkatkan likuiditas, profitabilitas dan nilai perusahaan (Nilsson, et al. 2010).

Manajemen modal kerja sangat penting dalam industri manufaktur. Ketika perusahaan tidak mampu mempertahankan tingkat modal 
kerja optimum, bisa diprediksi bahwa dalam jangka panjang perusahaan akan berada dalam keadaan insolvent atau ketidakmampuan pembayaran kewajiban-kewajiban yang jatuh tempo sehingga risiko kebangkrutan menjadi tinggi (Djarwanto, 2001).

Siklus konversi kas adalah waktu yang dibutuhkan perusahaan mulai dari proses pengeluaran uang untuk bahan baku sampai dengan penerimaan uang dari hasil penjualan, hubungan siklus konversi kas dengan operasional perusahaan adalah proses konversi uang kedalam aset jangka pendek dan kembali menjadi uang sebagai bagian dari aktivitas operasional yang berjalan (Gitman, 2006). Perputaran ini digunakan sebagai klasifikasi aset (dan hutang) sebagai aktiva lancar atau tidak lancar. Aktiva lancar diharapkan untuk dijual, dikumpulkan atau digunakan dalam waktu satu tahun atau selama perputaran operasional.

Menurut Brigham dan Houston (2010) siklus konversi kas memiliki tiga komponen, yakni days of sales in inventory (DSI), days of sales outstanding (DSO), days of payable outstanding (DPO). DSI menggambarkan kinerja dan efisiensi perusahaan dalam pengelolaan persediaan dari sudut pandang waktu. DSO adalah rata-rata waktu perusahaan untuk mengumpulkan piutang-piutang. Sedangkan DPO ialah waktu yang dibutuhkan perusahaan dalam melunasi hutang dagang.

Siklus konversi kas mampu memperkuat keputusan pendanaan jangka pendek untuk mengetahui kebijakan perusahaan dalam rangka memenuhi kesenjangan kas, dengan asumsi menahan pembayaran utang atau mempercepat periode penagihan piutangnya. Sebab dengan mengatur komponen ini secara efektif dan efisien perusahaan dapat mengurangi ketergantungan pendanaan dari pihak luar (Appuhami, 2008; Keown et al, 2003).

Manajemen modal kerja yang baik pada prinsipnya adalah keahlian dalam mengumpulkan kas penjualan secepat mungkin dan memperlambat pembayaran utang sampai batas waktu tertentu. Manajemen modal kerja yang efektif dan efisien sering dikaitkan dengan siklus konversi kas yang pendek (Hutchison et $a l, 2007)$. Siklus yang pendek mengindikasikan bahwa perusahaan mampu mengatur dan memproses persediaan serta piutang secara cepat, dan menunda pembayaran ke supplier. Pendeknya siklus konversi kas menandakan bahwa modal kerja yang dikelola perusahaan itu efektif.

Tujuan dari penelitian ini adalah untuk menguji dan menganalisis pengaruh profitabilitas, operating cash flow, ukuran perusahaan, pertumbuhan penjualan, quick ratio, dan debt ratio terhadap siklus konversi kas pada industri manufaktur di Indonesia.

Penelitian ini diharapkan bisa berkontribusi dalam pengambilan keputusan penjualan yang dilakukan perusahaan, sehingga efektivitas dan efisiensi manajemen perusahaan meningkat, selain itu penelitian ini dapat menambah pengetahuan tentang analisis hubungan siklus konversi kas dan manajemen modal kerja.

\section{METODE}

Pendekatan yang digunakan adalah pendekatan kuantitatif dengan menitikberatkan pengujian hipotesis dengan alat analisa Multiple Regression. Dimulai dengan uji asumsi klasik Normalitas, Autokorelasi, Multikolinearitas, dan Heteroskesdasitas

Jenis data yang digunakan adalah data sekunder berupa laporan keuangan tahunan dari beberapa perusahaan manufaktur yang terdaftar di BEI, Prosedur pengumpulan sampel menggunakan purposive sampling dimana metode ini mengambil sampel secara tidak acak. Metode ini digunakan untuk memperoleh batasan-batasan tertentu antara lain:

1. Perusahaan sampel yang terdaftar di Bursa Efek Indonesia tahun 2007-2011 dalam kelompok manufaktur yang menerbitkan laporan keuangan tahunan (financial statements) secara berturut-turut.

2. Perusahaan sampel mempunyai laporan keuangan yang berakhir 31 Desember

3. Perusahaan sampel memiliki semua data yang diperlukan secara lengkap.

Sehingga sampel penelitian yang digunakan sebanyak 128 perusahaan yang meliputi 18 kategori perusahaan manufaktur yang go public. Variabel-variabel diidentifikasi sebagai berikut:

Variabel dependen : Siklus Konversi Kas Variabel independent : Profitabilitas, operating cash flow, ukuran perusahaan, pertumbuhan 
penjualan, quick ratio dan debt ratio. berikut:

Hipotesis penelitian diringkas sebagai

1. Profitabilitas berpengaruh positif terhadap siklus konversi kas

2. Arus kas operasi berpengaruh negatif terhadap siklus konversi kas

3. Ukuran perusahaan berpengaruh negatif terhadap siklus konversi kas

4. Pertumbuhan penjualan berpengaruh negatif terhadap siklus konversi kas

5. Quick ratio berpengaruh positif terhadap siklus konversi kas

6. Debt ratio berpengaruh negatif terhadap siklus konversi kas

Model analisis disusun untuk mengetahui determinan yang mempengaruhi siklus konversi kas, model Regresi Linear Berganda yang digunakan adalah:

$\mathrm{CCC}_{\mathrm{it}}=\beta_{0}+\beta_{1} P R O F I T_{\mathrm{it}}+\beta_{2}$ CFit $_{\mathrm{it}}+\beta_{3} S I Z E_{\mathrm{it}}+$ $\beta_{4} G R O W T H_{\mathrm{it}}+\beta_{5} Q R_{\mathrm{it}}+\beta 6 \mathrm{DEBT}_{\mathrm{it}}+\varepsilon$

Keterangan:

\begin{tabular}{|c|c|}
\hline $\mathrm{CCC}_{\text {it }}$ & $\begin{array}{l}\text { : Siklus konversi kas } \\
\text { perusahaan i pada tahun } \mathrm{t}\end{array}$ \\
\hline PROFIT $_{\text {it }}$ & $\begin{array}{l}\text { : Profitabilitas perusahaan } \mathrm{i} \\
\text { pada tahun } \mathrm{t}\end{array}$ \\
\hline $\mathrm{CF}_{\text {it }}$ & $\begin{array}{l}\text { : Operating cash flow } \\
\text { perusahaan i pada tahun } \mathrm{t}\end{array}$ \\
\hline SIZE $_{\text {it }}$ & $\begin{array}{l}\text { : Ukuran perusahaan } \\
\text { perusahaan i pada tahun } \mathrm{t}\end{array}$ \\
\hline GROWTH $_{\text {it }}$ & $\begin{array}{l}\text { Pertumbuhan penjualan } \\
\text { perusahaan i pada tahun } \mathrm{t}\end{array}$ \\
\hline $\mathrm{QR}_{\text {it }}$ & $\begin{array}{l}\text { Quick ratio perusahaan i } \\
\text { pada tahun } \mathrm{t}\end{array}$ \\
\hline $\mathrm{DEBT}_{\text {it }}$ & $\begin{array}{l}\text { : Debt ratio perusahaan i pada } \\
\text { tahun } \mathrm{t}\end{array}$ \\
\hline$\beta_{0}$ & : Intersep persamaan regresi \\
\hline r & : Standart error \\
\hline
\end{tabular}

\section{HASIL}

Hasil analisis regresi linier berganda dengan variabel tergantung siklus konversi kas, dan variabel bebas yang terdiri dari profitabilitas (ROA), operating cash flow, ukuran perusahaan, pertumbuhan penjualan, quick ratio dan debt ratio pada industri manufaktur yang diproses dengan program SPSS tersaji pada tabel 1 .
Tabel 1 Hasil Analisis Regresi Linier Berganda

\begin{tabular}{lccc}
\hline \multicolumn{1}{c}{ Model } & Koefisien & $\mathrm{t}$ & Sig. \\
\hline Konstanta & 481,110 & 10,366 & 0,000 \\
\hline ROA & 28,886 & 1,834 & 0,067 \\
\hline OCF & $-25,278$ & $-2,671$ & 0,008 \\
\hline SIZE & $-13,105$ & $-8,008$ & 0,000 \\
\hline GROWTH & $-0,936$ & $-0,753$ & 0,452 \\
\hline QR & 0,838 & 1,257 & 0,209 \\
\hline DR & $-21,442$ & $-3,434$ & 0,001 \\
\hline Uji F & 15,191 & & 0,000 \\
\hline R Square & 0,128 & & \\
\hline & & &
\end{tabular}

Berdasarkan tabel diatas, persamaan regresi linier berganda yang dihasilkan adalah:

$\mathrm{CCC}_{\mathrm{it}}=481,110+28,886 \mathrm{ROA}-25,278 \mathrm{OCF}-$ 13,105SIZE - 0,936GROWTH + 0,838QR 21,442DR

Penjelasan persamaan regresi linier berganda di atas adalah sebagai berikut:

Variabel Operating Cash Flow (OCF), Ukuran Perusahaan (SIZE), dan Debt Ratio (DR) berpengaruh signifikan terhadap risiko saham perbankan karena nilai signifikansi $<0,05$. Sedangkan variabel Profitabilitas (ROA), Pertumbuhan Penjualan (GROWTH), dan Quick Ratio (QR) berpengaruh tidak signifikan terhadap risiko saham perbankan.

Nilai koefisien determinasi sebesar 0,128 menunjukkan bahwa siklus konversi kas (CCC) sebagai variabel dependen dapat dijelaskan sebesar 12,8\% oleh variabel profitabilitas (ROA), operating cash flow, ukuran perusahaan, pertumbuhan penjualan, quick ratio dan debt ratio, sedangkan $87,2 \%$ dapat dijelaskan oleh variabel lain diluar model.

Nilai signifikansi $F$ yang dihasilkan sebesar 0,000 menunjukkan bahwa secara bersama-sama variabel profitabilitas (ROA), operating cash flow, ukuran perusahaan, pertumbuhan penjualan, quick ratio, dan debt ratio berpengaruh signifikan terhadap risiko saham perbankan, dan model ini dapat dikatakan cukup baik untuk memprediksi risiko saham perbankan.

\section{PEMBAHASAN}

1. Pengaruh Profitabilitas

Variabel profitabilitas (ROA) berpengaruh positif dan tidak signifikan terhadap variabel siklus konversi kas, tidak 
sejalan dengan Deloof (2003) serta Raheman \& Nasr (2007) yang menghasilkan pengaruh negatif dari variabel profitabilitas terhadap siklus konversi kas. Hasil positif menunjukkan peningkatan profitabilitas dikaitkan dengan peningkatan siklus konversi kas. Perusahaanperusahaan yang memiliki tingkat profitabilitas tinggi cenderung memiliki siklus konversi kas yang panjang. Panjangnya siklus menunjukkan perusahaan memiliki manajemen modal kerja yang tidak efisien.

Meskipun tidak signfikan, hasil penelitian ini sesuai dengan hasil penelitian yang dilakukan oleh Nilsson et al (2010) yang menyatakan bahwa kenaikan profitabilitas dikaitkan dengan peningkatan siklus konversi kas.

\section{Pengaruh Operating Cash Flow}

Variabel arus kas operasi memiliki pengaruh negatif dan signifikan terhadap siklus konversi kas. Hasil penelitian sesuai dengan penelitian yang dilakukan Nilsson, et al. (2010) dengan hasil yang sama.

Perusahaan yang memiliki arus operasi kas yang tinggi memiliki manajemen modal kerja yang lebih efisien. Dapat diakatan perusahaan yang memiliki arus kas operasi yang tinggi memiliki periode siklus konversi kas yang pendek (Chiou et al, 2006).

Jeng-Ren et al (2006) dan Nwaeze et al (2006) juga menjabarkan bahwa semakin tinggi nilai arus kas operasi, menandakan bahwa perusahaan mempunyai kemampuan baik dalam menghasilkan kas. Hal ini juga mencerminkan kebijakan pengelolaan persediaan yang efisien dan kebijakan pengelolaan kredit yang baik sehingga hal tersebut mempengaruhi pendeknya siklus konversi kas perusahaan.

\section{Pengaruh Ukuran Perusahaan}

Variabel ukuran perusahaan memiliki pengaruh negatif dan signifikan terhadap siklus konversi kas, sesuai dengan Mongurt et al (2008) dan Nakamura \& Palombini (2008) yang juga menyatakan demikian. Hasil ini juga sesuai dengan Nilsson et al (2010) yang menyatakan bahwa semakin kecil ukuran perusahaan maka semakin lama siklus konversi kas yang terjadi, begitu pula sebaliknya.

Perusahaan dengan ukuran yang besar cenderung memiliki periode persediaan yang pendek dibanding perusahaan kecil (Moss \& Stine, 1993), perusahaan-perusahaan besar lebih berfokus pada manajemen operasi manufaktur seperti JIT (Just in Time). Dengan adanya sistem JIT perusahaan besar dapat memperpendek jumlah hari dalam persediaan, sehingga dapat memperpendek siklus konversi kas perusahaan.

\section{Pengaruh Pertumbuhan Penjualan}

Variabel pertumbuhan penjualan menunjukan hasil negatif dan tidak signifikan terhadap variabel siklus konversi kas. menyatakan bahwa perusahaan dengan tingkat pertumbuhan penjualan yang tinggi membutuhkan lebih banyak dana untuk membiayai peningkatan operasinya, sehingga perusahaan lebih fokus pada efisiensi pengelolaan manajemen modal kerja (Nilsson et $a l$, 2010; Jeng-Ren et al, 2006).

Hasil penelitian menunjukkan bahwa pertumbuhan penjualan berpengaruh negatif tetapi tidak signifikan, sehingga dapat dikatakan bahwa perusahaan yang tingkat pertumbuhannya tinggi belum tentu memiliki periode siklus konversi kas yang pendek.

\section{Pengaruh Quick Ratio}

Variabel quick ratio menunjukkan hasil pengaruh positif tetapi tidak signifikan terhadap variabel siklus konversi kas. Hal ini menunjukan bahwa perusahaan yang likuiditasnya tinggi belum tentu siklus konversi kas-nya panjang, karena perusahaan yang likuiditasnya tinggi cenderung memiliki kelebihan jumlah aset lancer (Moss \& Stine, 1993).

Tidak semua perusahaan dengan tingkat quick ratio yang tinggi memiliki siklus konversi kas yang panjang, perusahaan dengan nilai quick ratio tinggi menandakan bahwa tingkat likuditasnya baik. Berkaitan dengan periode pembayaran hutang dagang, perusahaan dengan tingkat likuditas yang baik mampu menjalin hubungan yang baik dengan kreditor yakni supplier.

\section{Pengaruh Debt Ratio}

Variabel debt ratio menunjukan hasil pengaruh negatif dan signifikan terhadap variabel siklus konversi kas. Hasil negatif dengan siklus konversi kas menunjukkan bahwa 
peningkatan rasio utang dikaitkan dengan pendeknya siklus konversi kas. Hal ini menunjukan bahwa perusahaan dengan rasio utang yang tinggi cenderung memiliki periode siklus konversi kas yang pendek.

Hasil penelitian ini sejalan dengan Nakamura \& Palombini (2010) yang menjelaskan adanya hubungan negatif antara rasio utang dengan siklus konversi kas. Perusahaan dengan rasio utang yang tinggi cenderung memiliki periode siklus konversi kas yang pendek. Pendeknya siklus menandakan manajemen modal kerja perusahaan yang efisien. Pengaruh negatif rasio utang terhadap siklus konversi kas disebabkan atas tingginya utang yang dapat mempengaruhi komponen dari siklus konversi kas yaitu periode persediaan dan periode hari pembayaran hutang dagang (Chiou et al, 2006).

\section{SIMPULAN DAN SARAN}

\section{Simpulan}

Berdasarkan atas analisis yang telah dijabarkan sebelumnya, hal-hal pokok yang dapat disimpulkan adalah sebagai berikut:

1. Profitabilitas berpengaruh positif tidak signifikan terhadap siklus konversi kas.

2. Operating cash flow berpengaruh negatif signifikan terhadap siklus konversi kas.

3. Ukuran perusahaan berpengaruh negatif signifikan terhadap siklus konversi kas.

4. Pertumbuhan penjualan berpengaruh negatif tetapi tidak signifikan terhadap siklus konversi kas.

5. Quick ratio berpengaruh positif tetapi tidak signifikan terhadap siklus konversi kas.

6. Debt ratio berpengaruh negatif signifikan terhadap siklus konversi kas.

7. Nilai R Square sebesar 0,128, menunjukan $12,8 \%$ variabilitas siklus konversi kas dapat dijelaskan oleh variabel profitabilitas, operating cash flow, ukuran perusahaan, pertumbuhan penjualan, quick ratio, dan debt ratio.Sisanya dijelaskan oleh variabel lain diluar model.

\section{Saran}

1. Perusahaan manufaktur sebaiknya memperhatikan variabel-variabel yang berpengaruh signifikan terhadap siklus konversi kas, karena variabel tersebut dapat dijadikan acuan perusahaan untuk mengevaluasi kinerjanya di masa yang akan datang.

2. Strategi yang dapat digunakan perusahaan manufaktur untuk mengelola siklus konversi kas adalah:

a. Memperpanjang waktu pembayaran utang dagang dengan tidak merusak kepercayaan supplier kepada perusahaan.

b. Efisiensi pengelolaan persediaan dengan cara: meningkatkan raw material turnover, menurunkan production cycle dengan teknik percepatan proses produksi dan meningkatkan "finished goods" turnover.

c. Mempercepat pengumpulan piutang dengan cara menawarkan privilege bagi pembayaran yang dilakukan lebih cepat, salah satunya dalam bentuk diskon. meningkatkan standar kredit merupakan salah satu strategi yang efektif untuk memperpendek periode konversi piutang.

d. Bagi perusahan manufaktur yang periode siklus konversi kas-nya panjang sebaiknya lebih memperhatikan pengelolaan manajemen modal kerjanya, sehingga kedepannya perusahaan bisa lebih efisien.

\section{DAFTAR RUJUKAN}

Appuhami, B. A. R. 2008. The Impact of Firm's Capital Expenditure on Working Capital Management: An Empirical Study across Industries in Thailand. International Management Review, 2008, Vol.4 No.1

Brigham, E. F. \& Joel F. H. 2010. Manajemen Keuangan. Edisi Kesebelas.

Chiou, Jeng-R, Li Cheng., \& Wu, H. W. 2006. The Determinats of Working Capital Management. The Journal Of American Academy of Business, Cambridge. Vol.10 No.1

Deloof, M. 2003. Does Working Capital Management Affect Profitability of Belgian Firms? Journal of businnes finance \& Accounting, Vol. 30 No. (3\&4)

Djarwanto. 2001. Pokok-pokok Analisa Laporan Keuangan. Edisi kedua. BPFE. Yogyakarta.

Gitman, L. J. 2006. Principles of Manajerial Finance. 10th Edition. Pearson Education. Boston.

Hutchison, P. D., Theodore, F II \& Susan B. A. 2007. Cash to Cash Analysis and Management: Certified Public 
55 | EKOBIS - Ekonomi Bisnis Vol. 24 No. 1 | Mei 2019| Halaman 50-55

Accountant. The CPA Journal. Aug 2007. Vol .77 No.8

Jeng-Ren, C., Li, C., \& W. Han-Wen. 2006.

The Determinants of Working Capital Management. Journal of American Academy of Business, Cambridge. Vol.10 No.1

Keown, A. J. 2003. Financial Management Principles and Applications. Ninth Edition. Prentice Hall. New Jersey

Mongurt, S., Darcy, F., Claudio, C. dan Johan, C. 2008. Determinats of Working Capital Management In Latin American Companies.

Moss, J.D., dan Stine, B. 1993. Cash Conversion Cycle and Firm Size: A study of Retail Firms. Journal of Managerial Finance, Vol.19 No.8

Nakamura, W.T and Natahalie, V.N.P. 2008. Key Factors In Working Capital Management In The Brazilian Market. Vol.52 No.1

Nilsson, H. 2010. The Effect of Company Characteristics on Working Capital Management. Umeå School of Business.

Nwaeze, E.T., Yang, S.S.M., dan Yin, Q.J. 2006. Accounting Information and CEO compensation: The role of cash flow from operations in the presence of earnings. Contemporary Accounting Research, Vol.23 No. 1

Raheman, A. dan Mohamed, N. 2007. Working Capital Management and Profitability Case Of Pakistani Firms. International Review of Business Research Papers. Vol.3 No.1, 279 - 300

Weston, J. F., \& Eugene F. B. 2005. Dasardasar Manajemen Keuangan. Jilid 2. Edisi kesembilan. Erlangga. Jakarta 
